\title{
Pollen morphology of Carapa species (Meliaceae) from the Brazilian Amazon
}

\author{
Alexsandro ZIDKO*, Luiz Antônio RODRIGUES², Cláudia Barbieri Ferreira MENDONÇA², Maria Lucia \\ ABSY $^{3}$, Marcos Gonçalves FERREIRA ${ }^{3}$, Paulo de Tarso Barbosa SAMPAIO ${ }^{4}$, Vania ESTEVES ${ }^{2}$ \\ 1 Instituto Nacional de Pesquisas da Amazônia, Laboratório de Propagação Vegetal, Avenida André Araújo 2936, Manaus AM, 69067-375. \\ 2 Universidade Federal do Rio de Janeiro, Museu Nacional, Botânica, Rio de Janeiro, RJ, 20940-040. \\ 3 Instituto Nacional de Pesquisas da Amazônia, CBI0, Laboratório de Palinologia, Manaus AM, 69067-375. \\ ${ }^{4}$ Instituto Nacional de Pesquisas da Amazônia, Coordenação de Tecnologia e Inovação, Manaus AM, 69067-375 \\ * Corresponding author: alexzidko@gmail.com
}

\section{ABSTRACT}

The crabwood (Carapa) represents an important source of natural resources. The objective of this work was to study the pollen morphology of the three species of Carapa (Meliaceae) registered in the Brazilian Amazon. The pollen grains were obtained from floral buds, pistillate and staminate flowers of Carapa guianensis, C. surinamensis and C. vasquezii. In order to explore the taxonomic implications of the pollen study for these species of Carapa, lactic acetolysis method was used for light microscopy study. Furthermore, the non-acetolyzed material was used in the study of the scanning electron microscopy. It was found that the three Carapa species present little variations in pollen morphology. Compared to the other species this study, Carapa vasquezii has higher values for the length and width of endoaperture; however, it has lower values for polar and equatorial diameter, equatorial diameter in polar view and apocolpium side.

KEYWORDS: Cedreloideae, crabwood, neotropical flora, palynotaxonomy.

\section{Morfologia polínica de Carapa (Meliaceae) espécies da Amazônia brasileira} RESUMO

A andiroba (Carapa) representa uma importante fonte de recursos naturais. O objetivo deste trabalho foi estudar a morfologia polínica das três espécies de Carapa (Meliaceae) registradas na Amazônia brasileira. Os grãos de pólen foram obtidos de botôes florais, flores pistiladas e estaminadas de Carapa guianensis, C. surinamensis e C. vasquezii. A fim de explorar as implicaçóes taxonômicas do estudo de pólen para estas espécies de Carapa, o material foi preparado de acordo com o método de acetólise láctico, permitindo a utilização de estudos de microscopia de luz. Além disso, o material não-acetolisado foi utilizado no estudo da microscopia eletrônica de varredura. $\mathrm{O}$ estudo mostra que as três espécies de Carapa apresentam pequenas variaçóes na morfologia polínica. Comparada com as outras espécies deste estudo, Carapa vasquezii têm valores mais elevados para o comprimento e largura da endoabertura, entretanto, tem valores inferiores para diâmetro polar, equatorial, diâmetro equatorial em vista polar e lado do apocolpo.

PALAVRAS-CHAVE: Cedreloideae, andiroba, flora neotropical, palinotaxonomia. 
Meliaceae is a predominantly tropical family with about 540 species in 120 genera, eight of them are native to the Americas (Ribeiro et al. 1999). The Cedreloideae subfamily stands out in the Neotropical Flora due to the presence of crabwood plants (Carapa) in soggy environments (Muellner et al. 2006). Crabwood represents an important source of natural resources. Its seeds provide one of the most used medicinal oils in Amazon. Kenfack (2011) reviewed the genus Carapa and recorded 27 species, 16 of them are found in Tropical Africa and 11 in the American Tropical forests. In Brazil, this genus is represented by three species: Carapa guianensis, Carapa surinamensis and Carapa vasquezii. Erdtman (1952) was the first author to study the subdivision of Meliaceae into subfamilies based on pollen morphology. Later, the pollen morphology of the genera Cedrela and Trichilia was studied by Roubik and Moreno (1991) and Silvestre-Capelato et al. (1996).

The pollen morphology of the three species of the genus Carapa found in the Brazilian Amazon was described by using optical microscopy and scanning electron microscopy (SEM) in the Laboratory of Palynology of the National Museum of Rio de Janeiro. Pollen grains were collected from the flower buds of voucher specimens deposited at the INPA's Herbarium. Analyzed material: Carapa guianensis Aubl.: BRAZIL, Amazon, Manaus, Adolpho Ducke Forest Reserve (0310'19” S, 6002'50" W), 06/VII/2010, collector, Zidko, A. 234719 (INPA). Carapa vasquezii Kenfack: BRAZIL, Amazon, Manaus, Experimental Station of Tropical Forestry (02'35'50” S, 6002'24” W), 16/III/2013, collector, Zidko, A. 250362 (INPA). Carapa surinamensis Miq. Stirp.: BRAZIL, Amazon, Manaus, Adolpho Ducke Forest Reserve (0310'19" S, 6002' $50^{\prime \prime}$ W), 28/I/2014, collector, Amoedo, S.C. 258150 (INPA). The pollen material was prepared according to the lactic acetolysis method in order to be analyzed in light microscope (Raynal and Raynal, 1971). The non-acetolyzed material was used to obtain the electron micrographs from scanning electron microscopy (Zeiss DSM 960). The pollen grains were spread on metallic supports previously covered with carbon tape. Next, a slight layer of palladium-gold was set over the grains for approximately three minutes. The polar diameter (PD) and the equatorial diameter (ED) in equatorial view of twenty-five pollen grains from the standard material were measured. The gathered data were used to perform statistical analyses, to calculate the arithmetic mean, standard deviation and the coefficient interval at 95\%. The arithmetic mean of 10 measurements was calculated to measure other parameters such as the equatorial diameter in polar view (EDPV), of the apocolpium side (AS), the apertures and the exine layers. The terminology and the pollen descriptions followed the criteria by Melhem et al. (2003) and Punt et al. (2007); the sexine size, shape, number of apertures and ornamentation pattern were analyzed. The denomination of the polar area and the size of the aperture is based on the polar area index of classification (Faegri and Iversen, 1964). The floral buds, pistillate and staminate flowers of Carapa guianensis, C. surinamensis and C. vasquezii were analyzed in order to assess variations in the pollen attributes and the presence of pollen grains in pistillate flowers.

Pollen description: The pollen grains of $C$. guianensis (Figures 1A, 1B, 1C, 1D, 1E); C. surinamensis (Figures 1F, $1 \mathrm{G}, 1 \mathrm{H}, 1 \mathrm{I}$ ) and $C$. vasquezii (Figures $1 \mathrm{~J}, 1 \mathrm{~K}, 1 \mathrm{~L}$ ) were analyzed. Medium size of the pollen grains (PD: 25.2-27.5; ED: 26.7-28.0 $\mu \mathrm{m}$ ), isopolar, circular amb, oblate spheroidal, polar area index (PAI) with variation between $(0.41-0.48$ $\mu \mathrm{m}), 4$-colporate, scabrate to rugulate sexine (Table 1,2). Aperture: 4 short ectocolpus (Figures 1A, 1F, 1J), narrow (the narrowest found in C. guianensis), with evident costa (Figures $1 \mathrm{~B}, 1 \mathrm{G}, 1 \mathrm{~K})$, lalongate endoapertures - the higher value for endoapertures length and width $(3.1 \times 5.6 \mu \mathrm{m})$ was recorded in C. vasquezii with prominent margin (Table 2). Exine thick, sexine thicker than the nexine, varying ornamentation in scabrous with perforations in C. guianensis (Figure 1E) and rugulate conspicuous with perforations in $C$. vasquezii and $C$. surinamensis (Figures 1I, 1L). Pistillate flowers of the analyzed species did not show pollen grains.

Pollen descriptions of the three Carapa species were very similar presenting pollen grains stephanocolporate (4-6 aperture), oblate spheroidal, isopolar and circular shape, common characteristics of the family, which are also presented in other palynological studies of Meliaceae (Erdtman, 1952; Roubik and Moreno, 1991; Large and Mabberley, 1994; Barth et al. 1998). Maués (2006) presented floral biology studies of C. guianensis in the Tapajós National Forest and recorded an average estimate of 6132 pollen grains per flower and every grains with about $26 \mu \mathrm{m}$ of polar diameter. Carreira and Secco (1984) performed pollen descriptions of C. guianensis herborized at the Goeldi Museum in Belém-PA, and considered the pollen grain surface as slightly corrugatedreticulated and the sexine a little thicker than the nexine.

Carapa vasquezii has $\mathrm{PD}$ and ED lower than those of other species (Table 1). It also presents lower EDPV and AS values. Such values are higher for the length and width of the endoaperture. The pollen study showed that the species $C$. guianensis has thick exine and sexine thicker than the nexine. Carreira and Secco (1984) found similar results. In this study, the pistillate flowers have sterile anthers, which corroborates the study of Maués (2006).

Considering the few pollen studies for the genus Carapa, especially the species found in Brazil. This study showed that the great similarity between the measured and morphologically described grains in this study confirms the taxonomic position of these species in the genus Carapa and in the Meliaceae family. In addition, this study about pollen morphology of the genus Carapa becomes necessary for future discussions 

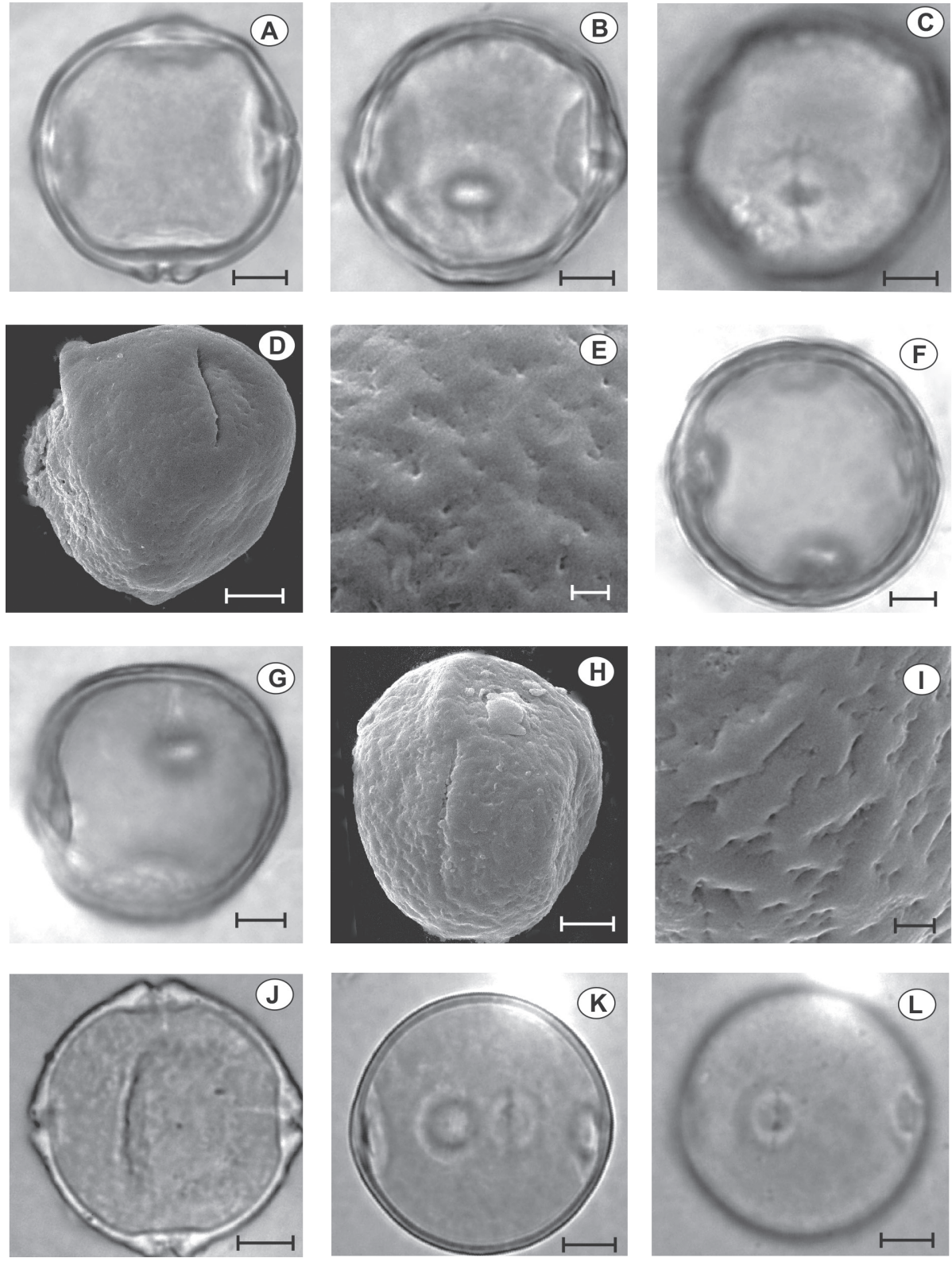

Figure 1. Photomicrographs and electron micrographs of pollen grains of Carapa spp. Carapa guianensis (panel A-E). A: polar view, optical section (LM); B: equatorial view, optical section (LM); C: aperture; D: aperture (SEM); E: detail of surface (SEM). Carapa surinamensis (panel F-I). F: polar view, optical section (LM); G: equatorial view, aperture; H: aperture (SEM); I: detail of surface (SEM). Carapa vasquezii (panel J-L). J: polar view, optical section (LM); K: equatorial view, optical section (LM); L: detail of surface and lateral view of aperture (SEM). Scale bars $=5 \mu \mathrm{m}(\mathrm{A}, \mathrm{B}, \mathrm{C}, \mathrm{D}, \mathrm{F}, \mathrm{G}, \mathrm{H}, \mathrm{J}, \mathrm{K}) ; 1 \mu \mathrm{m}(\mathrm{E}, \mathrm{I}, \mathrm{L})$.

Table 1. Dimensions $(\mu \mathrm{m})$ of pollen grains in equatorial view of species of Carapa (Meliaceae). Polar diameter (PD), Equatorial diameter (ED), Arithmetic mean $(\bar{x})$, Standard deviation (s) and Confidence interval, $\mathrm{Cl}(\mathrm{n}=25)$.

\begin{tabular}{lcccccc}
\hline \multirow{2}{*}{ Species } & \multicolumn{3}{c}{ PD } & \multicolumn{3}{c}{ ED } \\
\cline { 2 - 7 } & Range & $\overline{\mathrm{x}} \pm \mathrm{s}$ & $\mathrm{Cl} 95 \%$ & Range & $\overline{\mathrm{x}} \pm \mathrm{s}$ & $\mathrm{Cl} 95 \%$ \\
\hline C. guianensis & $25.0-27.5$ & $25.3 \pm 0.8$ & $24.9-25.6$ & $25.0-27.5$ & $27.1 \pm 0.9$ & $26.7-27.4$ \\
C. surinamensis & $25.0-30.0$ & $27.5 \pm 1.9$ & $26.7-28.2$ & $25.0-32.5$ & $28.0 \pm 2.1$ & $27.1-28.8$ \\
C. vasquezii & $25.0-27.5$ & $25.2 \pm 1.2$ & $20.0-30.4$ & $25.0-32.5$ & $26.7 \pm 2.6$ & $25.6-27.8$ \\
\hline
\end{tabular}


Table 2. Dimensions $(\mu \mathrm{m})$ of pollen grains in polar view of species of Carapa (Meliaceae). Equatorial diameter in polar view (EDPV), Apocolpium side (AS), Arithmetic mean $(\bar{x})$ and the measures $(\mu \mathrm{m})$ of the aperture and layers of the exine $(n=10)$.

\begin{tabular}{lccccccccc}
\hline \multirow{2}{*}{ Species } & EDPV & AS & \multicolumn{2}{c}{ Ectocolpus } & & \multicolumn{2}{c}{ Endoaperture } & \multicolumn{2}{c}{ Exine } \\
\cline { 2 - 10 } & $\overline{\mathrm{x}}$ & $\overline{\mathrm{x}}$ & length & width & length & width & margin & sexine & nexine \\
\hline C. guianensis & 28.5 & 13.0 & 15.0 & 1.0 & 2.8 & 4.8 & 1.2 & 2.0 & 1.0 \\
C. surinamensis & 30.0 & 12.2 & 15.0 & 1.5 & 2.7 & 4.8 & 1.4 & 2.0 & 1.0 \\
C. vasquezii & 25.5 & 12.1 & 14.5 & 1.4 & 3.1 & 5.6 & 1.2 & 2.0 & 1.0 \\
\hline
\end{tabular}

and taxonomic positions of the group, mainly about the specie Carapa vasquezii Kenfack, recently described and included into national territory.

\section{ACKNOWLEDGEMENTS}

The authors wish to thank Dr. Mike Hopkins, Curator of the Instituto Nacional de Pesquisas da Amazônia Herbarium. We also thank the Laboratório de Ultraestrutura Celular of the Instituto de Biofísica at the Universidade Federal do Rio de Janeiro (UFRJ); Noêmia R. Gonçalves, technical assistant of the Scanning Electron Microscope (SEM); Conselho Nacional de Desenvolvimento Científico e Tecnológico (CNPq) and Fundação de Amparo à Pesquisa do Estado do Rio de Janeiro (FAPERJ) for financial support of this study; CNPq and Coordenação de Aperfeiçoamento de Pessoal de Nível Superior (CAPES) for the fellowship awarded to some of the authors.

\section{REFERENCES}

Barth, O.M.; Justo, R.L.; Barros, M.A. 1998. Catálogo Sistemático do Pólen das Plantas Arbóreas do Brasil Meridional. XXX: Meliaceae. Revista Brasileira de Biologia, 58: 497-509.

Carreira, L.M.M.; Secco, R. de S. 1984. Morfologia polínica de plantas cultivadas no Parque do Museu Goeldi - III. Meliaceae. Boletim do Museu Paraense Emilio Goeldi. Botânica, 1: 5-22.

Erdtman, G., 1952. Pollen Morphology and Plant Taxonomy. Angiosperms. Almqvist and Wiksell, Stockholm, 539 pp.

Faegri, K.; Iversen, J. 1964. Textbook of Pollen Analysis. Hafner Publishing Co., New York, 237 p.

Kenfack, D. 2011. A Synoptic Revision of Carapa (Meliaceae). Harvard Papers in Botany, 16: 171-231.

Large, M.F.; Mabberley. D.J. 1994. The pollen of Dysoxylum (Meliaceae): the demise of Pseudocarpa. Botanical Journal of Linnean Society, 116:1-12.
Maués, M.M. 2006. Estratégias reprodutivas de espécies arbóreas e sua importância para o manejo e conservação florestal: Floresta Nacional do Tapajós (Belterra-PA). Tese (Doutorado) Universidade de Brasília. Instituto de Ciências Biológicas. Curso de Pós-graduação em Ecologia. Brasília, DF. 206p.

Melhem, T.S.; Cruz-Barros, M.A.V.; Corrêa, A.M.S.; MakinoWatanabe, H.; Silvestre-Capelato, M.S.; Gonçalves-Esteves, V. 2003. Variabilidade polínica em plantas de Campos do Jordão (São Paulo, Brasil). Boletim do Instituto de Botânica, 16: 1-104.

Muellner, A.N.; Savolainem, V.; Samuel, R.; Chase, M.W. 2006. The mahogany family "out-of-Africa": Divergence time estimation, global biogeographic patterns inferred from plastid $r b c \mathrm{~L}$ DNA sequences, extant, and fossil distribution of diversity. Molecular Phylogenetics and Evolution, 40: 236-250.

Punt, W.; Hoen, P.P.; Blackmore, S.; Nilsson, S.; Le Thomas, A. 2007. Glossary of pollen and spore terminology. Review of Palaeobotany and Palynology, 143: 1-81.

Raynal, A.; Raynal, J. 1971. Une technique de préparation des grains de pollen fragiles. Adansonia, 11: 77-79.

Ribeiro, J.E.L.S.; Hopkins, M.J.G.; Vicentini, A.; Sothers, C.A.; Costa, M.A. da S.; Brito, J.M. de. et al., 1999. Flora da Reserva Ducke. Guia de identificação das plantas vasculares de uma floresta de terra-firme da Amazônia Central. INPA/DFUD. Manaus, INPA. 800p.

Roubik, D.W.; Moreno, J.E. 1991. Pollen and spores of Barro Colorado Island. Monographs in Sistematic Botany from the Missouri Botanical Garden. 270pp.

Silvestre-Capelato, M.S.F.; Cruz-Barros, M.A.V.; Rodrigues, A.A.G. 1996. Flora polínica da Reserva do Parque Estadual das Fontes do Ipiranga (São Paulo, Brasil). Família: 117 Meliaceae. Hoehnea, 23: $135-140$.

Recebido em 23/12/2015

Aceito em 24/03/2016 